\title{
A Study on the Perception of SMEs on Foreign Exchange Risk Management
}

\author{
B. Vijayalakshmi ${ }^{1, *}$, G. Subashini ${ }^{1}$, M. Jayalakshmi ${ }^{2}$, C. Umayal ${ }^{1}$ \\ ${ }^{1}$ Department of Business Management, Sri Padmavati Mahila Visvavidyalayam, (Women's University), Tirupati-517502, India \\ ${ }^{2}$ Department of Management Studies, Siddhartha Institute of Engineering \& Technology, Puttur-517583, A.P., India
}

Received October 1, 2021; Revised November 15, 2021; Accepted December 13, 2021

\section{Cite This Paper in the following Citation Styles}

(a): [1] B. Vijayalakshmi, G. Subashini, M. Jayalakshmi, C. Umayal, "A Study on the Perception of SMEs on Foreign Exchange Risk Management," Universal Journal of Accounting and Finance, Vol. 10, No. 1, pp. 95-101, 2022. DOI: 10.13189/ujaf.2022.100110.

(b): B. Vijayalakshmi, G. Subashini, M. Jayalakshmi, C. Umayal (2022). A Study on the Perception of SMEs on Foreign Exchange Risk Management. Universal Journal of Accounting and Finance, 10(1), 95-101. DOI: 10.13189/ujaf.2022.100110.

Copyright $\bigcirc 2022$ by authors, all rights reserved. Authors agree that this article remains permanently open access under the terms of the Creative Commons Attribution License 4.0 International License

\begin{abstract}
The promotion of Small and Medium enterprises (SMEs) has continued to remain an important and integral part of Indian development strategy and is known to play a vital role in the global economic landscape. Despite the fact that Government of India has formulated many policies to promote export expansion of SMEs, they have traditionally focused more on domestic markets and the export performance of this sector in the global market has been unimpressive. Although SMEs want to exploit the international opportunities and want to become more export oriented, many barriers impede the growth performance of Indian SMEs to meet the challenges of emerging trends in globalization. This paper specifically aims at finding the perception of the SMEs in determining their hedging strategies to mitigate the foreign exchange risk. The study is performed by considering primary and secondary data. The primary data were collected from 71 selected export traders through structured questionnaire and analyzed using suitable statistical tools. From the study, it is concluded that the SMEs with high turnover prefer to adopt currency derivatives, especially forward contracts whereas the SMEs with lower turnover prefer natural or non-hedging strategy. It is also recommended that the banking sector can also step forward to give information on currency price movements to their clients as an additional service.
\end{abstract}

Keywords FX Rate, Conversion Risk, SMEs, Hedging
Strategies, Risk Perception

\section{Introduction}

As India moves forward in an era of globalization, small and medium enterprises (SMEs) became more and more integrated with the world economy. Furthermore, progressive globalization for the past two decades has created an opportunity for the SMEs to enter into the international market through global strategy beyond national borders. Recognizing the need for larger access of SMEs to capital, the Indian government has taken various initiatives. It has started a comprehensive policy package for SMEs comprising fiscal, credit, infrastructure and technology. Despite an elaborate and dynamic policy framework, the participation of SMEs in global trade is very meager due to high transaction risk and increasing volatility in exchange rate in recent years.

Although SMEs are becoming important players in international business, the progress of Indian SMEs continues to be hindered by many barriers such as dearth of reliable data on overseas markets, lack of ability to interact with potential overseas customers, unfamiliarity with export rules, procedures and documentation, lack of familiarity on hedging strategies, difficulty in identifying foreign business opportunities, and inadequate access to 
export finance etc., which impede the growth performance of Indian SMEs to meet the challenges of emerging trends in globalization.

Further, as currency fluctuations can adversely impact SMEs, it is very important from the SMEs' perspective to manage their foreign exchange risk efficiently and effectively. It is well known factor that exchange rates are always dynamic, and their fluctuations can have big impact on businesses - positive and negative. Hence, there is no other choice but SMEs, which have to proactively understand and estimate their foreign exchange exposures in which they have their foreign transactions. Further, they have to develop well-defined risk mitigation strategies and processes in place with astute risk personnel.

It has been reported that exportation has shown a gradual increase with time due to different static and dynamic factors [1]. Despite the fact that the large SME sector is considered as one of the successful economies [2], many factors influence the export performances which are classified as internal and external export barriers. However, these barriers of trade have been debilitated due to the timely intervention of World Trade Organization (WTO). It is also assumed that healthy export market may have a positive correlation with the sustainable growth [3].

Given the wide range of products manufactured in the small scale sector, the nature of the export composition makes it certain that the products from SMEs have improved quality or exportability with the supportive interventions in order to achieve product / process innovations, diversification and larger market access. Considering the impact of globalization process on developing countries, it is amply clear that the SMEs face major challenges in strengthening their human resources as well as financial investments for the advantage of trade and investment opportunities [4]. Hence, the relationship between economic growth and international trade assumes paramount importance in the formulation of world economy $[5,6]$. Plethora of contemporary policy initiatives have identified specific barriers such as constraints in lack of human resources, financial restrictions and constraints due to limited or asymmetric information on foreign markets. Presently, the number of SMEs participating in exports is 1.27 lakh and the government proposes increasing the number to five lakh and twofold their export output. As a result, SMEs have gained an untapped export potential to enter into the foreign markets by overcoming the trade-specific hurdles through globalization process [7].

Most small- and medium-sized enterprises (SMEs) consider themselves to be an exporter to a large international group which continues to purchase from the SME even its factory is shifted to a foreign country. Interestingly, SME do not venture to export when their business is performing well at home. Paradoxically, they start considering an export strategy only when the circumstances of their business worsen at home [8]. In general, the firm needs to address the following basic principles at the time of venturing into export business such as market opportunities, foreign exchange risk, import and export financing and challenges of doing business in a foreign market [5].

To minimize the foreign exchange risk of loss, every business needs to have forex risk management practices in place. Therefore, the selection of foreign markets and entry modes reside at the very heart of any international strategy [9]. Firms under a non-hedging strategy never purchase a forward foreign exchange contract to cover exchange rate risk. An alternative strategy is always-hedge, also referred to as hedging strategy. This paper investigates the efficacy of simple strategies for hedging foreign exchange risk. The strategies are: to always hedge, to never hedge, to hedge when the forward rate is at a premium, to hedge only when the premium is large, and a strategy based upon relative purchasing power parity (PPP). All the above hedging strategies are based on the use of currency derivatives $[10,11,12]$. Firms are likely to place more emphasis on internal hedging techniques than currency derivatives [13].

\section{Research Design}

Research design adopted for the study was descriptive in nature and the data were analyzed based on primary data source. The stratified random sampling method has been adopted with a sample size of 100 export units. The primary data is collected through a structured questionnaire from the respondents to know their perception, level of knowledge, hedging strategy and factors affecting the strategy. Proposed Hypotheses were tested by using statistical tools like Independent Sample test, One-way ANOVA, Mean and Regression Analysis by using Software packages SPSS 21.0 and AMOS 18 for data analysis. The scope of the study is confined only to the state of Tamil Nadu, and also it is limited to Exporters. The samples were collected from the following 10 industries namely Gem and Jewellery, Leather, sea food, Processed Food, Spice Board, Garments, Coir, Automobile, Engineering and Coconut.

Multinational companies and the financial institutes have their own exclusive departments on FX analysis with specialists appointed to cater their needs. Also, the Banks, ADs and Insurance companies are all the members of Foreign Exchange Dealers Association of India, where they get entire price and cost details based on their quotes. An effort is being made in order to fill the gap by analyzing the various aspects like factors influencing hedging strategy, perception and level of knowledge of SMEs on FX risk.

\section{Objectives of the Study}

1. To predict the factors determining the hedging strategy 
2. To analyze the perception of Foreign Exchange risk by SMEs

3. To know the level of knowledge of SMES on FX risk and mitigation tools

\section{Hypothesis Framed}

$\mathrm{H}_{01}$ : No significant relationship exists between volume of business and interest in Hedging strategy

$\mathrm{H}_{02}$ : No significant relationship exists between nature of business and reason for Hedging strategy

$\mathrm{H}_{03}$ : No significant relationship exists between nature of business \& hedging strategies familiar

$\mathrm{H}_{04}$ : No significant relationship exists between volume of business $\&$ hedging strategies familiar

\section{Analysis and Interpretation}

Table 1 shows the attained thresholds of skewness and kurtosis in descriptive statistics. For normally distributed data, the skewness will be within the range of +2 to -2 and the kurtosis will be within the range of +3 to -3 . It is observed from the table that for the all the study variables, the skewness are within -0.769 (minimum) to 1.089 (maximum) whereas kurtosis statistical values are ranging from -2.017 to 0.180 . Therefore, it is confirmed that the data are normally distributed.

\section{$H_{01}$ : No significant relationship between volume of business and interest in Hedging}

From the table 2, the group statistics of independent sample $t$ test were anlyzed between interest in hedging and volume of the business. Out of 71 samples enquired,
36 respondents were found with an interest in hedging while remaining 35 respondents were found with no interest in hedging. Respondents who showed interest in hedging have their business volume ranging between 5 and 25 crores whereas respondents who did not show interest in hedging have the business volume of less than 5 crores of rupees.

A t-test is a statistic method used to determine if there is a significant difference between the means of two groups based on a sample of data. Referring the table 3 of independent sample t-test result, it is evident that Levene's test for equality of variance is significant since $\mathrm{F}$ value is 21.904 with 69 degrees of freedom. This test is statistically significant at one percent level of significance $(\mathrm{P}=0.000<0.001)$. Therefore, we reject the null hypothesis "No significant relationship exists between volume of business and Interest in Hedging" and conclude that the variance in volume of business with interest in hedging is significantly different than that of not interested in hedging.

\section{$\mathrm{H}_{02}:$ No significant relationship between nature of business and reason for Hedging}

In table 4, Analysis of Variance in one-way approach is used to test whether the nature of business shows a significant relationship with reason for hedging. The test results showed in the table confirms that the nature of business in terms of type of respondents who are engaged in has a significant relationship with reason for hedging. Since F statistic is 6.818 with 70 degrees of freedom and $\mathrm{P}$ value is statistically significant at one percent level $(\mathrm{P}=$ $0.000<0.001)$, the null hypothesis "There is no significant relationship between nature of business and reason for Hedging" is rejected.

Table 1. Skewness and Kurtosis for Normality Test - Descriptive Statistics

\begin{tabular}{|c|c|c|c|c|c|c|}
\hline & Minimum & Maximum & \multicolumn{2}{|c|}{ Skewness } & \multicolumn{2}{c|}{ Kurtosis } \\
\cline { 2 - 7 } & Statistic & Statistic & Statistic & Std. Error & Statistic & Std. Error \\
\hline Business Nature & 1.00 & 10.00 & 0.048 & 0.285 & -0.846 & 0.563 \\
\hline Nature of Ownership & 1.00 & 3.00 & 0.226 & 0.285 & -1.710 & 0.563 \\
\hline Volume of Business & 1.00 & 4.00 & 0.816 & 0.285 & -0.465 & 0.563 \\
\hline Nature of Trade & 1.00 & 2.00 & -0.769 & 0.285 & -1.451 & 0.563 \\
\hline Duration of Business & 1.00 & 4.00 & 0.080 & 0.285 & -1.056 & 0.563 \\
\hline Duration of Export Business & 1.00 & 4.00 & 0.282 & 0.285 & -0.868 & 0.563 \\
\hline Employee Knowledge on FX & 1.00 & 3.00 & -0.113 & 0.285 & -1.803 & 0.563 \\
\hline Hedging Interest & 0.00 & 1.00 & -0.029 & 0.285 & -2.058 & 0.563 \\
\hline Reason for Hedging & 1.00 & 6.00 & 0.371 & 0.285 & -1.453 & 0.563 \\
\hline Familiarity on Hedging Strategies & 1.00 & 5.00 & 0.955 & 0.285 & 0.038 & 0.563 \\
\hline Hedging Strategies Preferred & 1.00 & 7.00 & 1.089 & 0.285 & 0.180 & 0.563 \\
\hline
\end{tabular}


Table 2. Group Statistics - Volume of Business and Interest in Hedging

\begin{tabular}{|c|c|c|c|c|c|}
\hline & Hedging Interest & N & Mean & Std. Deviation & Std. Error Mean \\
\hline Business & Yes & 36 & 2.4444 & 1.05409 & 0.17568 \\
\cline { 2 - 6 } Volume & No & 35 & 1.3429 & 0.53922 & 0.09114 \\
\hline
\end{tabular}

Table 3. Independent Samples Test

\begin{tabular}{|c|c|c|c|c|c|c|c|c|c|c|}
\hline & \multicolumn{2}{|c|}{\begin{tabular}{|c|c|} 
Levene's Test for \\
Equality of \\
Variances
\end{tabular}} & \multicolumn{7}{|c|}{ t-test for Equality of Means } \\
\hline & & \multirow[t]{2}{*}{$\mathbf{F}$} & \multirow[t]{2}{*}{ Sig. } & \multirow[t]{2}{*}{$\mathbf{T}$} & \multirow[t]{2}{*}{ df } & \multirow{2}{*}{$\begin{array}{c}\text { Sig. } \\
\text { (2-tailed) }\end{array}$} & \multirow{2}{*}{$\begin{array}{c}\text { Mean } \\
\text { Difference }\end{array}$} & \multirow{2}{*}{$\begin{array}{l}\text { Std. Error } \\
\text { Difference }\end{array}$} & \multicolumn{2}{|c|}{$\begin{array}{c}95 \% \text { Confidence Interval } \\
\text { of the Difference }\end{array}$} \\
\hline & & & & & & & & & Lower & Upper \\
\hline \multirow{2}{*}{$\begin{array}{l}\text { Business } \\
\text { Volume }\end{array}$} & $\begin{array}{l}\text { Equal variances } \\
\text { assumed }\end{array}$ & 21.904 & 0.000 & 5.520 & 69 & 0.000 & 1.10159 & 0.19958 & 0.70344 & 1.49974 \\
\hline & $\begin{array}{c}\text { Equal variances not } \\
\text { assumed }\end{array}$ & & & 5.566 & 52.464 & 0.000 & 1.10159 & 0.19792 & 0.70452 & 1.49866 \\
\hline
\end{tabular}

Table 4. One Way ANOVA-Nature of Business and Reason for Hedging

\begin{tabular}{|c|c|c|c|c|c|}
\hline & Sum of Squares & Df & Mean Square & F & Sig. \\
\hline Between Groups & 166.457 & 5 & 33.291 & 6.818 & 0.000 \\
\hline Within Groups & 317.402 & 65 & 4.883 & & \\
\hline Total & 483.859 & 70 & & & \\
\hline
\end{tabular}

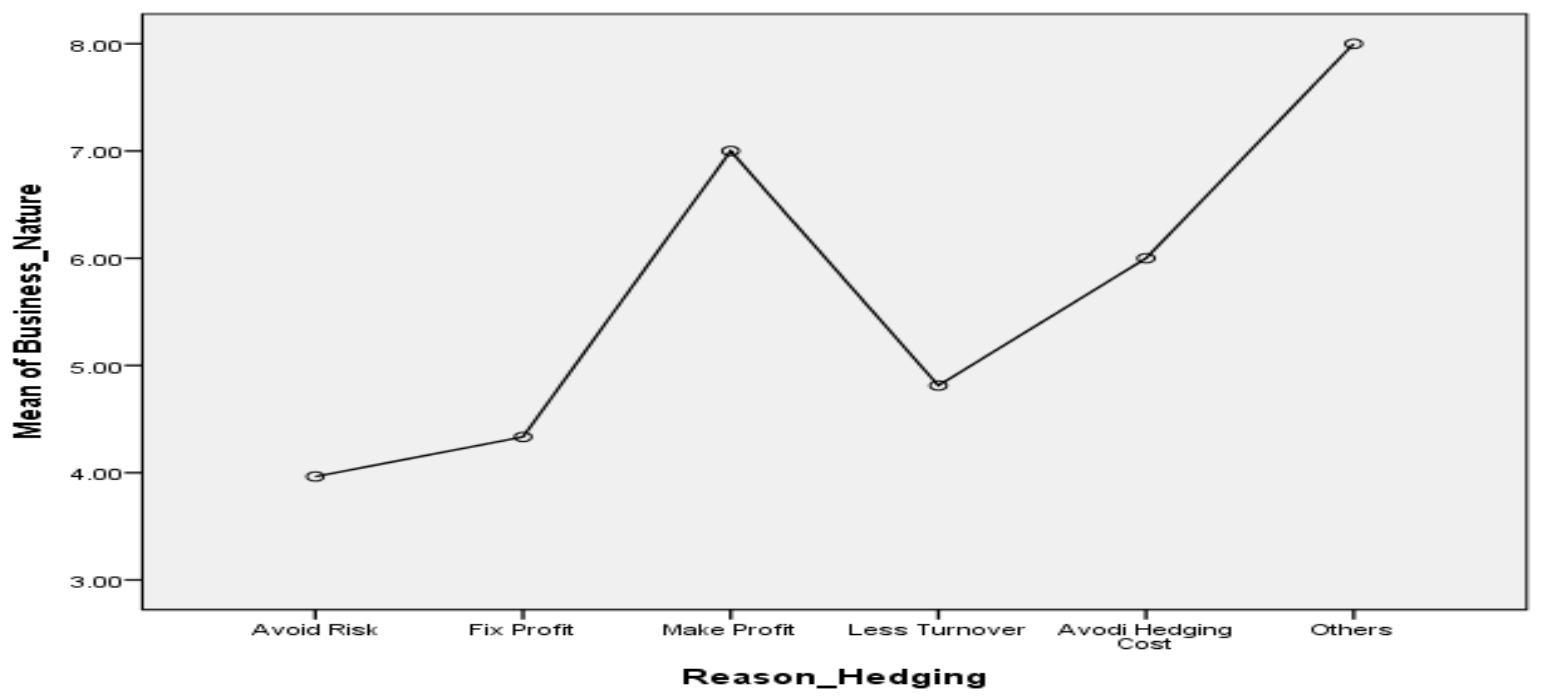

Graph 1. Mean Graph for Nature of Business and Reason for Hedging

Form the graph-1, it is observed that automobiles, garments, and engineering type of businesses significantly associated with making profits, avoid hedging cost and others as the reasons for hedging. The nature of remaining businesses is associated with the reasons like avoiding risk, fixing the profit and lesser turnover.

$H_{03}:$ No significant relationship between nature of business \& hedging strategies familiar

Table 5. One Way ANOVA - Nature of Business and Hedging Strategies Familiar

\begin{tabular}{|c|c|c|c|c|c|}
\hline & $\begin{array}{c}\text { Sum of } \\
\text { Squares }\end{array}$ & Df & $\begin{array}{c}\text { Mean } \\
\text { Square }\end{array}$ & F & Sig. \\
\hline $\begin{array}{c}\text { Between } \\
\text { Groups }\end{array}$ & 106.051 & 4 & 26.513 & 4.632 & 0.002 \\
\hline Within Groups & 377.809 & 66 & 5.724 & & \\
\hline Total & 483.859 & 70 & & & \\
\hline
\end{tabular}

In the table-5, Analysis of Variance in one-way approach is performed to test whether the nature of business shows a significant relationship with the familiarity on hedging strategies. The test result shown in the above table confirms that the nature of business in terms of business type has a significant relationship with familiarity with hedging strategies since $F$ statistic is 4.632 with 70 degrees of freedom and $\mathrm{P}$ value is statistically significant $(\mathrm{P}=0.002<0.05)$ at five percent level.

$H_{04}:$ No significant relationship between volume of business \& hedging strategies familiar 
Table 6. One Way ANOVA - Volume of Business and Hedging Strategies Familiar

\begin{tabular}{|c|c|c|c|c|c|}
\hline & $\begin{array}{c}\text { Sum of } \\
\text { Squares }\end{array}$ & Df & Mean Square & F & Sig. \\
\hline $\begin{array}{c}\text { Between } \\
\text { Groups }\end{array}$ & 11.032 & 4 & 2.758 & 3.071 & 0.022 \\
\hline Within Groups & 59.278 & 66 & 0.898 & & \\
\hline Total & 70.310 & 70 & & & \\
\hline
\end{tabular}

It is found from the test of one-way Analysis of Variance calculated in the above table- 6 that there is a significant relationship between volume of business and familiarity on hedging strategies. The mean square value between different volumes of business is 2.758 while the mean square within different hedging strategies familiar groups is $0.898 . \mathrm{F}$ statistic is 3.071 with 70 degree of freedom and the significant value is 0.022 which is less than 0.05 at five percent level of significance. Therefore, we reject the null hypothesis "There is no significant relationship between volume of business \& hedging strategies familiar".

From the graph-2, it can be observed that business firms with higher turnover are familiar with currency derivative products like currency futures, forward contracts and firms with lesser and medium volume of business turnover adopts no natural hedging and internal hedging strategies like pricing in INR etc.

Table 7. Model Summary-Factors determining Hedging Strategy

\begin{tabular}{|c|c|c|c|c|}
\hline Model & R & R Square & $\begin{array}{c}\text { Adjusted R } \\
\text { Square }\end{array}$ & $\begin{array}{c}\text { Std. Error of the } \\
\text { Estimate }\end{array}$ \\
\hline 1 & $0.398^{\mathrm{a}}$ & 0.159 & 0.094 & 1.57458 \\
\hline
\end{tabular}

a. Predictors (Constant): Risk Attitude, Turnover Percent, Nature of Business, Business Volume, Export Duration
Table-7 shows the overall model summary of regression analysis performed between factors of hedging practices and risk attitude, turnover percent, nature of business, volume of business and export duration. The correlation coefficient is 0.398 . $\mathrm{R}$ square is 0.159 which account for 16 percent of change in dependent factors (risk attitude, turnover percent, nature of business, volume of business, and export duration)

Table 8. ANOVA

\begin{tabular}{|c|c|c|c|c|c|c|}
\hline \multicolumn{2}{|r|}{ Model } & $\begin{array}{c}\text { Sum of } \\
\text { Squares }\end{array}$ & Df & $\begin{array}{c}\text { Mean } \\
\text { Square }\end{array}$ & $\mathbf{F}$ & Sig. \\
\hline \multirow{3}{*}{1} & Regression & 30.422 & 5 & 6.084 & 2.454 & $0.042^{\mathrm{b}}$ \\
\hline & Residual & 161.155 & 65 & 2.479 & & \\
\hline & Total & 191.577 & 70 & & & \\
\hline
\end{tabular}

ANOVA table-8 presented above shows whether there is a liner regression that can fit between factors of hedging practices and risk attitude, turnover percent, nature of business, volume of business, and export duration. Withstand to the test results, it can be accepted that there exists linear relationship among the factors of hedging practices and risk attitude, turnover percent, nature of business, volume of business, and export duration. Since $P$ value is statistically significant for $\mathrm{F}=2.454 ; \mathrm{df}=70$; $\mathrm{p}=0.042<0.05$.

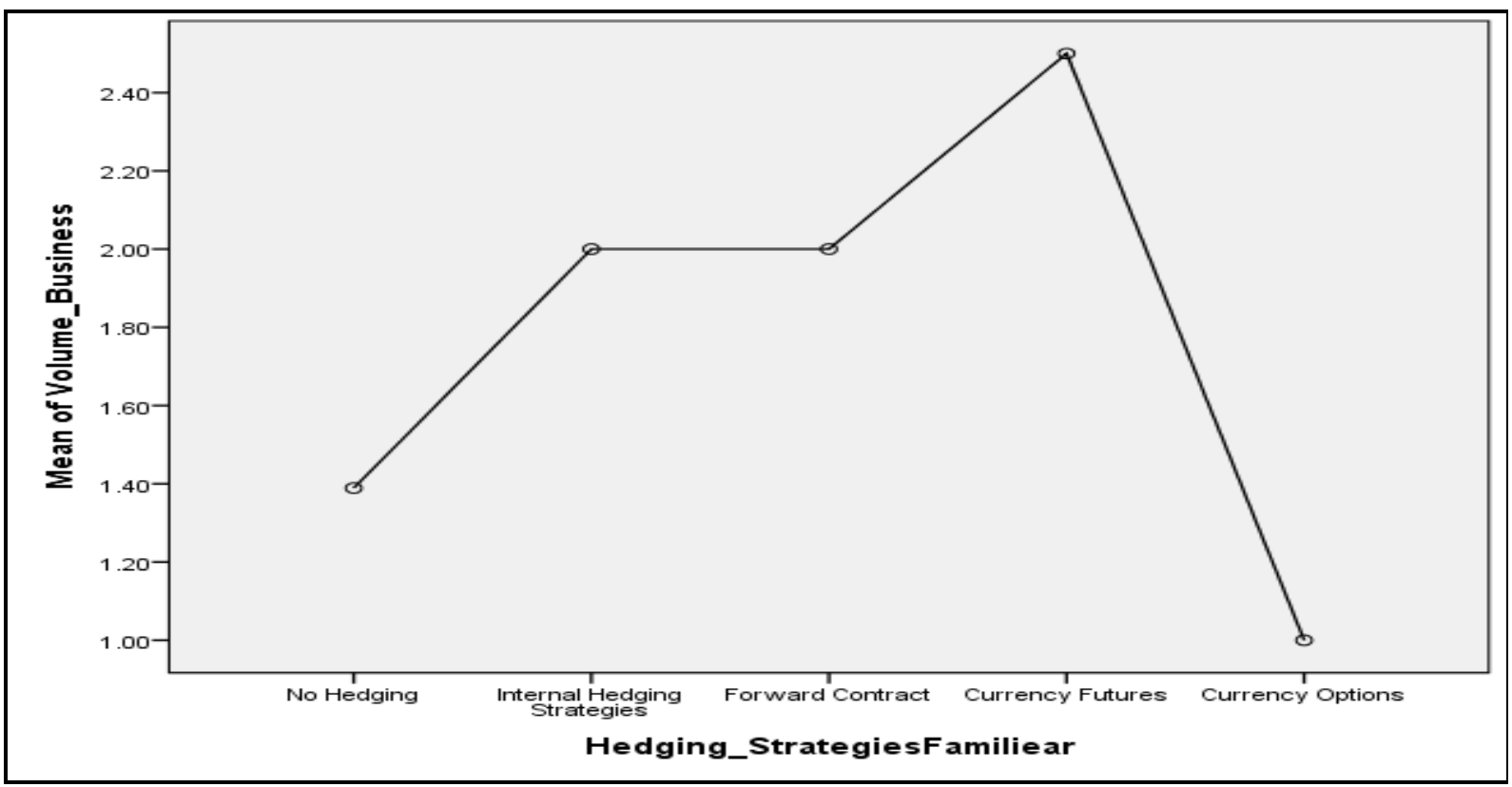

Graph 2. Mean Graph for Nature of Business and Hedging Strategies Familiar 
Table 9. Coefficients

\begin{tabular}{|c|c|c|c|c|c|c|}
\hline & \multirow[t]{2}{*}{ Model } & \multicolumn{2}{|c|}{ Unstandardized Coefficients } & \multirow{2}{*}{$\begin{array}{c}\begin{array}{c}\text { Standardized } \\
\text { Coefficients }\end{array} \\
\text { Beta }\end{array}$} & \multirow[t]{2}{*}{$\mathbf{t}$} & \multirow[t]{2}{*}{ Sig. } \\
\hline & & B & Std. Error & & & \\
\hline \multirow{6}{*}{1} & (Constant) & 1.062 & 0.894 & & 1.189 & 0.239 \\
\hline & Nature of Business & -0.001 & 0.075 & -0.002 & -0.017 & 0.986 \\
\hline & Export Duration & 0.250 & 0.241 & 0.146 & 1.038 & 0.303 \\
\hline & Business Volume & 0.516 & 0.223 & 0.312 & 2.315 & 0.024 \\
\hline & Turnover Percent & -0.002 & 0.006 & -0.038 & -0.312 & 0.756 \\
\hline & Risk Attitude & 0.024 & 0.314 & 0.009 & 0.076 & 0.940 \\
\hline
\end{tabular}

Linear relationship coefficient which is also known as path coefficient (beta $\beta$ ) between hedging practice and business volume is statistically significant $(\beta=0.312 ; \mathrm{P}=$ $0.024<0.05$ ) whereas the remaining factors (1) hedging practice and nature of business $(\mathrm{P}=0.986>0.05),(2)$ hedging practice and Export Duration $(\mathrm{P}=0.303>0.05)$, (3) hedging practice and Turnover percent $(\mathrm{P}=0.756>$ $0.05)$, (4) hedging practice and risk attitude $(\mathrm{P}=0.940>$ 0.05 ) are not statistically significant (Table-9).

\section{Findings}

Based on the above analysis, it is found that the data collected are normally distributed since skewness and kurtosis are within in the range of +2 to -2 and +3 to -3 respectively. The variance in volume of business with interest in hedging is significantly different than that of "Not interested" in hedging i.e. Respondents with business turnover from 5 to 25 crores are interested in hedging and less than 5 crores turnover are not interested in hedging their FX risk. Respondents who belong to the industries like automobiles, garments and engineering are hedging their transaction risk for the reasons like making profits and avoiding hedging cost. On the other hand rest of the industries prefers hedging for the reasons such as avoiding risk, fixing the profit and lesser turnover. Mean square between the groups is 26.513 and within the group is 5.724 with $\mathrm{F}$ statistic is 4.632 with 70 degrees of freedom and at five percent level of significance. Since the calculated $\mathrm{P}$ value is 0.002 which is lesser than 0.05 , the study confirms that the nature of business in terms of business type has a significant relationship with familiarity on hedging strategies. The mean square value between different volumes of business is 2.758 while the mean square within different hedging strategies familiar groups is 0.898 . F statistic is 3.071 with 70 degree of freedom and the significant value is 0.022 which is less than 0.05 at five percent level of significance. Therefore, it is confirmed that there exists a significant relationship between volume of business and hedging familiar strategies. Hence, the business firms with higher turnover are familiar with currency derivative products like currency futures, forward contracts and firms with lesser and medium volume of business turnover adopts no (natural) hedging and internal hedging strategies like pricing in INR etc. The overall model summary of regression analysis showed the correlation coefficient as 0.398 and $\mathrm{R}$ square as 0.159 which accounts for 16 percent of change in dependent factors (risk attitude, turnover percent, nature of business, volume of business, and export duration). The Linear relationship coefficient or path coefficient (beta $\beta$ ) between hedging practice and business volume is statistically significant with values of $\beta=0.312 ; \mathrm{P}=0.024<0.05$ whereas remaining independent factors are not statistically significant.

\section{Suggestions and Conclusions}

Among the SMEs, the firms with higher turnovers can go for currency derivatives especially forward contract if the tenure of the order execution is lengthier. Otherwise, for short term orders and for lower turnovers they can prefer natural or non-hedging strategy since the cost of the forward contract will sweep the volatility in the price fluctuation. SMEs have always found to be inhibited in accessing financial markets, instruments, foreign currency usage norms that favor the large and established companies. Most of the Indian SMEs believe that expansion into new international markets is a necessary step for improved financial performance and global reach.

The government has also made it mandatory for both private and public sector banks to cater to the requirements of SMEs. SME exchanges are specialized equity markets, differentiated from the main exchange that provides risk capital for promising entrepreneurs, promoting innovation crucial for sustainable economic growth. Since USD is the most tradable and preferable currency and the INR is getting depreciated against USD in floating exchange rate system, the exporters can go for natural hedging if the cost of forward contract is high. On the whole, the respondents are taking their decisions on hedging their transaction risk based on their experience. 


\section{REFERENCES}

[1] Duangporn Siawsurat, and Yalcin Cahit Önel. Internationalization stages of SMEs through Exporting: A qualitative study of internationalization stages of Thai SME exporters and their export barriers, Umeå School of Business, Master thesis, pp. 62, 2011.

[2] Thorsten Beck, and Ross Levine. Stock markets, banks, and growth: Panel evidence, Journal of Banking and Finance, Vol. 28, No. 3, pp. 423-442, 2004 http://www.sciencedirect.com/science/article/pii/S0378-42 66(02)00408-9.

[3] Gibson Tim (2015). Why aren't SMEs exporting? Telegraph Media Group Limited. http://www.telegraph.co. uk/business/sme-management/why-arent-smes-exporting/

[4] OECD (2004). $2^{\text {nd }}$ OECD Conference of Minsters responsible for Small and Medium- Sized enterprises (SMEs), Istanbul Turkey 325, pp. 1-59. 2004.

[5] Wellington Garikai Bonga. Challenges faced by SMEs on exportation and possible strategies, Social Science Research Network, pp. 1-8, 2014, DOI:10.2139/ssrn.23998 78

[6] Wellington Garikai Bonga, Tawanda E. Shenje, and Rodrick Sithole. Export sector contribution to economic growth in Zimbabwe: A causality analysis, The International Journal of Business \& Management, Vol. 3, No. 10, pp. 452-463, 2015, www.theijbm.com.

[7] Victor Carlsson and Muhammad S Khan. SMEs modes of entering in China: A multiple case study of Swedish firms entering in China. Linnaeus University, Sweden, Master thesis, 2014.

[8] Paul Vuolle R. 8 Steps to a strong export strategy for SMEs. Industry Week, 2015.http://www.industryweek.com/growt h-strategies/8-steps-strong-export-strategy-smes.

[9] Adam J Koch. Selecting overseas markets and entry modes: Two decision processes or one?, Marketing Intelligence \& Planning, Vol. 19, No. 1, pp. 65-75, 2001.

[10] Mark R. Eaker, and Dwight M. Grant. Cross-hedging foreign currency risk, Journal of International Money and Finance, Vol. 6, No. 1, pp. 85-105, 1987, http://www.sciencedirect.com/science/article/pii/0261-560 6(87)90015-5.

[11] Imad A. Moosa. What is wrong with Market-Based forecasting of exchange rates?, International Journal of Business and Economics, Vol. 3, No. 2, pp. 107-121, 2004, https://www.researchgate.net/publication/228416231.

[12] Matthew R. Morey and Marc W. Simpson. To hedge or not to hedge: The performance of simple strategies for hedging foreign exchange risk, Journal of Multinational Financial Management, Vol. 11, No. 2, pp. 213-223, 2001, http://www.sciencedirect.com/science/article/pii/S1042-44 4X(00)00050-5.

[13] Antti Hakkarainen, Nathan Lael Joseph, Eero Kasanen, and Vesa Puttonen, The Foreign exchange exposure management practices of Finnish industrial firms, Journal of International Financial Management \& Accounting, Vol, 9, No. 1, pp. 34-57, 2002, https://doi.org/10.1111/1467-64 6X.00029. 